\title{
Erratum to: NT-020 treatment reduces inflammation and augments Nrf-2 and Wnt signaling in aged rats
}

Antwoine Flowers ${ }^{1 \dagger}$, Jea-Young Lee ${ }^{1 \dagger}$, Bethany Grimmig ${ }^{1}$, Sandra Acosta ${ }^{1}$, Charles Hudson ${ }^{2}$, Brent Small ${ }^{3}$, Cyndy D. Sanberg ${ }^{4}$ and Paula C. Bickford ${ }^{1,2^{*}}$

\section{Erratum}

Upon publication of the original article [1], it was noticed that Bethany Grimmig was missed off the author list. She has now been included and this has been updated in the original article.

\begin{abstract}
Author details
'Department of Neurosurgery Brain Repair, and Center of Excellence for Aging and Brain Repair, University of South Florida Morsani College of Medicine, MDC-78, 12901 Bruce B Downs, Blvd, Tampa, FL 33612, USA. ${ }^{2}$ Research Service, James A Haley Veterans Hospital, Tampa, FL, USA. ${ }^{3}$ School of Aging Studies, University of South Florida, 4202 E. Fowler Ave, Tampa, FL 33620, USA. ${ }^{4}$ Natura Therapeutics, Inc., Tampa, FL, USA.
\end{abstract}

Received: 17 August 2016 Accepted: 17 August 2016

Published online: 05 September 2016

\section{Reference}

1. Flowers A, Lee J-Y, Grimmig B, Acosta S, Hudson C, Small B, Sanberg CD, Bickford PC. NT-020 treatment reduces inflammation and augments Nrf-2 and Wnt signaling in aged rats. J Neuroinflammation. 2016;12:174.

\footnotetext{
* Correspondence: pbickfor@health.usf.edu

${ }^{\dagger}$ Equal contributors

'Department of Neurosurgery Brain Repair, and Center of Excellence for Aging and Brain Repair, University of South Florida Morsani College of Medicine, MDC-78, 12901 Bruce B Downs, Blvd, Tampa, FL 33612, USA ${ }^{2}$ Research Service, James A Haley Veterans Hospital, Tampa, FL, USA Full list of author information is available at the end of the article
}

Submit your next manuscript to BioMed Central and we will help you at every step:

- We accept pre-submission inquiries

- Our selector tool helps you to find the most relevant journal

- We provide round the clock customer support

- Convenient online submission

- Thorough peer review

- Inclusion in PubMed and all major indexing services

- Maximum visibility for your research

Submit your manuscript at www.biomedcentral.com/submit 